(C) 2018 International Journal of Nursing and Midwifery Science (IJNMS)

This is an Open Access article distributed under the terms of the Creative Commons Attribution 4.0 International License which permits unrestricted non-commercial use, distribution, and reproduction in any medium, provided the original work is properly cited.

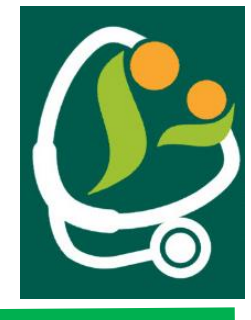

\title{
PROGRESSIVE MUSCLE RELAXATION EFFECT ON THE LEVEL ANXIETY OF CANCER PATIENTS UNDERGOING CHEMOTHERAPY
}

\section{Enny Virda Yuniarti ${ }^{1}$, Ima Rahmawati2}

Bina Sehat PPNI Health Science Institute of Mojokerto

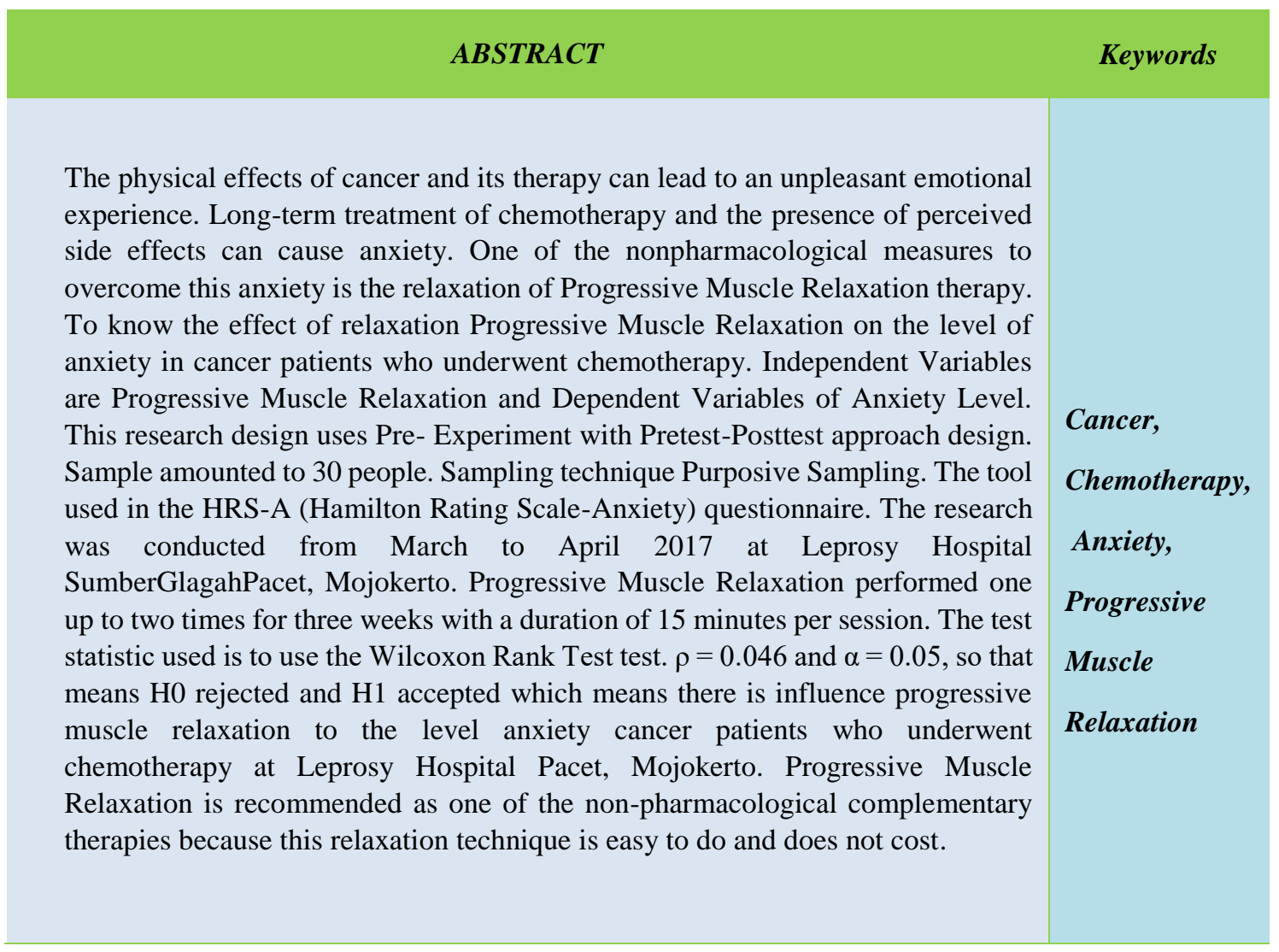




\section{INTRODUCTION}

Lifestyle changes and current environmental exposure cause a shift in the pattern and type of disease, one of which is the increased incidence of cancer among other diseases (Haryati, 2009 in Nova, 2016).Cancer is a disease caused by the growth of cells of body tissue that is not normal. People still believe that a cancer diagnosis is thought to have an immediate meaning of death, and a painful death. As a result of all that the diagnosis of cancer is seen as an enormous life crisis (Danielle Gale, 2000). Chemotherapy is one of the modalities of cancer treatment selected primarily to deal with locally advanced and metastatic cancer. Patients undergoing chemotherapy treatment will experience psychological problems as a result of cancer travel or side effects of chemotherapy that can minimize the chances of healing and also result in such patients wanting to stop chemotherapy treatment (Star, 2012).

Based on GLOBOCAN data. International Agency for Research on Cancer, it is known that in 2012 there are 14,067,894 new cases of cancer and $8,201,575$ cancer deaths worldwide. Nationally prevalence of cancer in the population of all ages in Indonesia in 2013 at $1.4 \%$ or an estimated 347,792 people. The province of East Java is the province with the highest estimated cancer patients, ie61,230 people (Infodatin, 2015).

Based on medical record data at SumberGlagah Hospital,
PacetMojokerto, the number of patients treated in 2015 Oncology surgery hospital is 1,660 people, while from the year 2016 is 2,906 people. While those who are underwent chemotherapy in 2015 as many as 888 people. In the year 2016 who underwent chemotherapy as much as 920 people And based on preliminary study results through interviews using the HRS-A (Hamilton Rating Scale for Anxiety) questionnaire, five respondents of cancer patients in the Chemotherapy Room of Leprosy Hospital SumberGlagah Pacet Mojokerto. Data obtained 3 Respondents experiencing severe anxiety (60\%), one respondent experienced moderate anxiety (20\%), and one respondent experienced mild anxiety (20\%) Which was characterized by symptoms of chest pounding, frequent urination, and anxiety. Some of these symptoms indicate that the patient has anxiety.

Management Anxiety alone was associated with pharmacological (benzodiazepine) and nonpharmacological (psychotherapy). However, in general, hospitalization is focused on restoring physical condition regardless of the patient's psychological condition (Canisti, 2008 in Yolanda, 2016). Relaxation was first introduced by a Chicago psychologist name Jacobson. This physiological method was developed to counteract the tension and anxiety called Progressive Relaxation (Solehati and Kosasih, 2015). Progressive Muscle Relaxation refocuses on a muscle activity by identifying tense muscles 
and decreasing the tension by doing relaxation techniques to get relaxed feelings. The purpose of Progressive Muscle Relaxation Technique decreases muscle tension, anxiety, neck and back pain, high blood pressure, heart frequency, metabolic rate (Herod, 2010 in Setyoadi, 2011).

Thus, a study focusing on Progressive Muscle Relaxation on the anxiety level of cancer patients Chemotherapy can be done to control the level of anxiety in patients as an action to overcome non-pharmacological (psychotherapy) therapy on cancer clients who underwent chemotherapy. Therefore, researchers are interested to identify the extent to which the "Effect of Progressive Muscle Relaxation on the anxiety level of cancer patients undergoing Chemotherapy."

\section{RESEARCH METHODS}

The research design used was PreExperimental. The design used is One Group Pretest-Postest Population in this study is all cancer patients who underwent chemotherapy at the hospital Source Glagah Pacet Mojokerto. The average patient who underwent chemotherapy was 30 people. Sampling in this study using Nonprobability Sampling is a technique that does not provide equal opportunities for members of the population to be selected to be sample. Non- probability sampling technique. The samples used in this study were some cancer patients who underwent chemotherapy at SumberGlagah Hospital, Pacet Mojokerto. Samples that met the inclusion criteria. The inclusion criteria to be respondents in this study are: Able to move independently, co-operative patient and willing to be a research respondent, can see, can write and read, Never had a Progressive Muscle Relaxtation relaxation technique, stage 3 and 4. The exclusion criteria that become respondents in this research are: Experiencing other comorbid diseases that can not be done progressive Muscle Relaxtation, patients who are not anxious. Progressive Muscle Relaxation is given to patients who will do chemotherapy with the following procedure techniques: Doing Progressive Muscle Relaxation exercise 1-2 times a day for 3 weeks with a duration of 15-20 minutes, Stretch the muscles for \pm 5-7 seconds and relax for \pm 10 seconds in 15 movements, Position sitting or supine, and Progressive Muscle Relaxation exercise is done before the patient does chemotherapy.

The researcher will explain the research objectives, benefits, and research procedures, then explain the technique of PMR implementation in patients undergoing chemotherapy. The implementation of Progressive Muscle Relaxation has conducted on March 20, 2017 - April 21, 2017. Then on April 21, 2017, researchers conducted data collection posttest questionnaire level of anxiety but before the researchers conducted the data collection. The researcher first evaluates PMR exercises that the patient has done at home and then gives an anxiety questionnaire to be use as post-test data. Anxiety gauge using HRS-A (Hamilton Rating Scale for 
Anxiety), which consists of 14 groups of symptoms.

This study uses Wilcoxon Sign Rank Test statistics. Wilcoxon Signed Rank statistical test This test is used to test the hypothesis difference between two observations, with the following conditions: a) Used for one sample b) each sample has 2 observations (before and after) c) is a comparative test between 2 observations d) scale the lowest ordinal data or may be used against quantitative data or intervals or ratios if the requirements for such data are not met. If the value of Tw arithmetic $\leq$ the value of $\mathrm{Tw}$ table on the corresponding $\alpha$, then Ho is rejected and H1 accepted.

\section{RESULTS}

\section{Custom Data}

Table 2.1 Frequency distribution of anxiety levels of cancer patients undergoing chemotherapy before being given Progressive Muscle Relaxation

\begin{tabular}{cccc}
\hline No & Anxiety & f & \% \\
\hline 1 & low & 11 & 36,7 \\
\hline 2 & mid & 13 & 43,3 \\
\hline 3 & high & 6 & 20,0 \\
\hline & Total & 30 & 100
\end{tabular}

\begin{tabular}{cccccc}
3 & Severe & 6 & 20 & 3 & 10 \\
\hline & Total & 30 & 100 & 30 & 100
\end{tabular}

Table 2.1 above shows that anxiety levels of cancer clients who underwent chemotherapy before Progressive
Muscle Relaxation has give that of 30 respondents most experienced mild anxiety 11 people $(36.7 \%)$, moderate anxiety 13 people $(43.3 \%)$, and severe anxiety people $(20.0 \%)$.

Table 2.2 Frequency distribution of anxiety levels of cancer patients undergoing chemotherapy after being given Progressive Muscle Relaxation.

\begin{tabular}{|c|c|c|c|}
\hline No & Anxiety level & $\mathbf{f}$ & $\%$ \\
\hline 1 & Low & 12 & 40 \\
\hline 2 & mild & 15 & 50 \\
\hline 3 & hard & 3 & 10 \\
\hline & total & 30 & 100 \\
\hline
\end{tabular}

Table 2.2 above shows that anxiety levels of cancer clients are undergoing chemotherapy before being given Progressive Muscle Relaxation that from 30 respondents mostly experienced mild anxiety 12 people $(40 \%)$, moderate anxiety 15 people $(50 \%)$, and severe anxiety three people $(10 \%)$.

Tabel 2.3 Frequency distribution of anxiety levels of cancer patients undergoing chemotherapy before and after being given Progressive Muscle Relaxation

International Journal of Nursing and Midwifery Science (IJNMS), Volume 2, Issue 1, April 2018 


\begin{tabular}{llllll}
\hline & & \multicolumn{3}{c}{ PMR Technique } \\
\hline No & $\begin{array}{c}\text { Anxiety } \\
\text { Level }\end{array}$ & \multicolumn{2}{c}{$\begin{array}{l}\text { before } \\
\text { being } \\
\text { given } \\
\text { PMR }\end{array}$} & $\begin{array}{c}\text { after } \\
\text { being } \\
\text { given } \\
\text { PMR }\end{array}$ \\
\hline & & F & $\%$ & F & $\%$ \\
\hline 1 & Low & 11 & 36,7 & 12 & 40 \\
\hline 2 & Mild & 13 & 43.3 & 15 & 50 \\
\hline 3 & Hard & 6 & 20 & 3 & 10 \\
\hline & Total & 30 & 100 & 30 & 100 \\
\hline
\end{tabular}

Table 2.3 above shows that from 30 respondents before and after being given Progressive Muscle Relaxation it was found that before being given Progressive Muscle Relaxation there were 11 people $(36,7 \%)$ experiencing mild anxiety after given Progressive Muscle Relaxation got that experienced mild anxiety 12 people (40\%), Prior to being given Progressive Muscle Relaxation there were 13 people $(43.3 \%)$ experiencing moderate anxiety after being given Progressive Muscle Relaxation obtained with moderate anxiety 15 people (50\%), Prior to Progressive Muscle Relaxation there were 6 people (20\%) experiencing anxiety weight after being given Progressive Muscle Relaxation obtained with severe anxiety 3 people (10\%). Based on the result of calculation of statistical test of wilcoxon Signed Ranks test, the $\mathrm{Z}$ value obtained is $-2,000$ with $P$ value $0.046<(0,05)$. The price of Ztabel $(-1,645)$ and the price of Zhitung $(-2,000)$ is bigger than $(-1,645)$ so that the meaning of $\mathrm{H} 0$ is rejected, so there is the effect of progressive muscle relaxtation on the anxiety level of cancer patients undergoing chemotherapy

\section{DISCUSSION}

Several factors that influence the effectiveness of Progressive Muscle Relaxation are Education. Based on table 4.5 shows the majority of junior high school respondents is 20 people (63.3\%). Where age affects a person psychologically, the level of education can also reduce the sense of being unable to deal with anxiety. The higher a person's education will be easier and more able to face stress that exists. People who have a higher education will respond more rationally than those with lower educated or uneducated. Anxiety is a response that can be learned thus low education becomes a factor supporting the occurrence of anxiety. This is because clients with low education are unaware or few his knowledge of various matters relating to advanced diagnosis and management experience. By Kaplan \& Sadock theory, 1997 in Lufta \& Maliya, 2007) that a sufficient level of education will more easily identify the stressors within themselves and from outside themselves. The level of education also affects awareness and understanding of the stimulus. Table 2.3 above shows that from 30 respondents before and after being given Progressive Muscle Relaxation it was found that PreTest was give Progressive Muscle Relaxation there were 11 people $(36,7 \%)$ had mild anxiety, 13 people $(43,3 \%)$ experienced moderate anxiety, six people $(20 \%)$ experienced severe anxiety. But after 3 weeks of Progressive Muscle Relaxation performed by the respondents at home where each 15 minute session was conducted Post-test using a Hamilton Rating Scale for 
Anxiety (HRS-A) with mild anxiety as 12 people (40\%), moderate anxiety of 15 people $(15 \%)$, and severe anxiety of 3 people $(10 \%)$.

The result of statistic test of Wilcoxon Signed Ranks test by using SPSS got $\rho=$ 0,046 and $\alpha=0,05$, so that mean $\mathrm{H} 0$ refused, and $\mathrm{H} 1$ accepted which means there is influence progressive muscle relaxation to anxiety level of the cancer patient who underwent chemotherapy at Leprosy Hospital Pacet, Mojokerto. However, the results obtained from the statistical test Wilcoxon Signed Ranks test results obtained data with low significance value. This can happen by various factors one of them is the environment around the respondent is less conducive so that it can cause the concentration of the patient is disturbed, the body position of the patient is not in a relaxed state, no one supervises or guides, at the time of the Progressive Muscle Relaxation there is no controlling of the patient according to SOP Progressive Muscle Relaxation. This is proven based on the theory according to Setyoadi (2011), Progressive Muscle Relaxation therapy techniques there are things that need to be considered one of them is the preparation, be it the preparation of tools and the environment, the chairs, the pillow, and the quiet and silent environment, really relax, It takes about 20-50 seconds to make muscles relaxation.

Viewed from other factors, According to Greenberg 2002, in Damamik 2005 Progressive Muscle Relaxation will give a significant influence as much as three times the exercise. The time required to perform this technique so that it can cause the maximum effect is for 1-2 weeks with a duration of time 15 minutes/times. In this study due to chemotherapy patients is a patient of One Day Care (ODC), who will go home on the same day after undergoing chemotherapy. So patients do Progressive Muscle Relaxation exercises at home so researchers cannot provide training to respondents so that when viewed from the observation results Progressive Muscle Relaxation exercise average respondents in 3 weeks cycle time chemotherapy respondents only 12 times the exercise and when joining with the theory then with only 12 rehearsals this result will not be seen. Unlike if researchers can directly train chemotherapy patients and performed by SOP Progressive Muscle Relaxation then the results obtained will have a significant effect.

\section{CONCLUSION}

There is Influence of Progressive Muscle Relaxation on the anxiety level of cancer patients who underwent chemotherapy at Leprosy Hospital Sumberglagah, Pacet, Mojokerto with the results obtained from statistical test Wilcoxon Signed Ranks test obtained results obtained p-value $0,046<0,05$ with price $Z$ table that is $(-1,645)$ and the price of $\mathrm{Z}$ arithmetic $(-2,000)$ is larger than $(-1,645)$ so that it means rejected $\mathrm{H} 0$ which means there is a low progressive muscle relaxation effect on the anxiety level of cancer patients undergoing chemotherapy at Leprosy

International Journal of Nursing and Midwifery Science (IJNMS), Volume 2, Issue 1, April 2018 
Hospital Pacet, Mojokerto.

\section{SUGGESTION}

It is expect that the results of this study could provide input for hospitals to be considered as a complementary therapy to overcome anxiety and can be used as an alternative independent nursing actions that can be used by nurses to reduce the level of anxiety in cancer patients who underwent chemotherapy

\section{REFERENCES}

Infodatin.2015.Pusatdata \& Informasi kementerian kesehatan RI.Stop Kanker. Didapatkan dari: (www.depkes.go.id/download.php \%3Ffile\%3Ddownload/pusdatin/inf odatin./infodatin-

kanker.pdf.)(Diakses tanggal 30 November2016).

Bintang,Y.A.2012.GambaranTingkat kecemasan,stress\&depresi pada pasienkankeryangmenjalani kemoterapi di salah satu RS di kota Bandung. Didapatkan dari (http:// jurnal.unpad.ac.id./ejournal/article /vi ew/719)(Diakses tanggal 30November2016).

LPPM.2016.Buku Panduan Penyusuanan KTI dan Skripsi.Mojokerto:LPPM Stikes Bina Sehat PPNI Mojokerto

Maryani,Ani.2009.Pengaruh Progressive Muscle Relaxation terhadap Kecemasan, Mual dan muntah setelah kemoterapi pada pasien kanker payudara di Rs. DR.Hasan Sadikin Bandung. Didapatkan dari:(http://

jurnal.usu.ac.id/ejournal/article/vi e w/4564345) (Diakses tanggal 1

Desember 2016)

Maryani,F.M.2014.Pengaruh Terapi

Relaksasi Otot Progresif terhadap tingkat kecemasan pada pasien kanker payudara. Diaksestanggal30 November 2016 dari http:// jurnal.usu.ac.id/ejournal/article/vi e w/4564

Solehati, Kosasih.2015. Konsep \& Aplikasi Relaksasi dalam Keperawatan Maternitas.Bandung:Refika Aditama

Infodatin.2015.Republic of Information \& Ministry of Health RI.Stop Cancer. Obtained from: (www.depkes.go.id/download.php \%3Ffile\%3Ddownload/pusdatin/i nfodatin./infodatin-kanker.pdf.) (Retrieved November 30, 2010).

Bintang, Y.A.2012.GambaranTingkat anxiety, stress \& depression in patients cancer undergoing chemotherapy in one hospital in the city of Bandung. Obtained from (http: // jurnal.unpad.ac.id./ejournal/article /vi ew / 719) (Retrieved dated 30November2016).

LPPM.2016.KTI and Thesis Breeding Manual Bookbook.Mojokerto: LPPM Stikes Bina Sehat PPNI Mojokerto

Maryani, Ani.2009. Progressive Muscle Relaxation Effects on Anxiety, Nausea and vomiting after chemotherapy in breast cancer patients in Rs. DR.Hasan Sadikin Bandung. Obtained from: (http: // jurnal.usu.ac.id/ejournal/article/vi e w / 4564345) (Retrieved December 1, 2016) 
Maryani, F.M.2014. Effect of Progressive Relaxation Muscle Relaxation on anxiety levels in breast cancer patients. Diaksestdate November 30, 2016 from http: // jurnal.usu.ac.id/ejournal/article/vi e w / 4564

Solehati, Kosasih.2015. Concepts \& Applications of Relaxation in Maternity Nursing.Bandung: Refika Aditama 